\section{Cool-season Turfgrass Response to Bispyribac-Sodium}

\author{
Darren W. Lycan and Stephen E. Hart ${ }^{1}$ \\ Department of Plant Biology and Pathology, Rutgers, The State University of \\ New Jersey, 59 Dudley Road, New Brunswick, NJ 08901
}

Additional index words. chewings fine fescue, Festuca rubra L. subsp. commutata Gaud., kentucky bluegrass, Poa pratensis L., perennial ryegrass, Lolium perenne L., tall fescue, Festuca arundinacea (L.) Schreb., herbicide phytotoxicity

\begin{abstract}
Previous research has demonstrated that bispyribac-sodium can selectively control established annual bluegrass (Poa annua L.) in creeping bentgrass (Agrostis stolonifera L.). Annual bluegrass is also a problematic weed in other cool-season turfgrass species. However, the relative tolerance of other cool-season turfgrass species to bispyribac is not known. Field experiments were conducted at Adelphia, N.J., in 2002 and 2003 to gain understanding of the phytotoxic effects that bispyribac may have on kentucky bluegrass (Poa pratensis $\mathbf{L}$.), perennial ryegrass (Lolium perenne L.), tall fescue (Festuca arundinacea (L.) Schreb.), and chewings fine fescue (Festuca rubra $\mathbf{L}$. subsp. commutata Gaud.). Single applications of bispyribac at 37 to $296 \mathrm{~g} \cdot \mathrm{ha}^{-1}$ were applied to mature stands of each species on $11 \mathrm{June}$, 2002 and 10 June, 2003. Visual injury was evaluated and clippings were collected 35 and 70 days after treatment (DAT). Visual injury at 35 DAT increased as bispyribac rate increased. Kentucky bluegrass was least tolerant to bispyribac with up to $28 \%$ injury when applied at $296 \mathrm{~g} \cdot \mathrm{ha}^{-1}$. Injury on other species did not exceed $20 \%$. Initial injury on perennial ryegrass, tall fescue, and chewings fine fescue was primarily in the form of chlorosis, while kentucky bluegrass exhibited more severe stunting and thinning symptoms. Bispyribac at rates from 74 to $296 \mathrm{~g} \cdot \mathrm{ha}^{-1}$ reduced kentucky bluegrass clipping weights by $19 \%$ to $35 \%$, respectively, as compared to the untreated control at 35 DAT in 2002. Initial visual injury on perennial ryegrass, tall fescue, and chewings fine fescue dissipated to $\leq \mathbf{5 \%}$ by $\mathbf{7 0}$ DAT. However, recovery of kentucky bluegrass was less complete. These studies suggest that bispyribac-sodium has potential to severely injure kentucky bluegrass. Injury on perennial ryegrass, tall fescue, and chewings fine fescue appears to be less severe and persistent; therefore, bispyribac can be used for weed control in these species. Chemical names used: 2,6-bis [(4,6-dimethoxy-2pyrimidinyl)oxy]benzoic acid (bispyribac-sodium).
\end{abstract}

Bispyribac-sodium is an acetolactate synthase (ALS, EC 2.2.1.6) -inhibiting herbicide belonging to the pyrimidinyl carboxy herbicide family (Shimizu et al., 2002). ALS-inhibiting herbicides block formation of the branchedchain amino acids leucine, isoleucine, and valine within a susceptible plant. Postemergence applications of bispyribac can selectively control barnyardgrass (Echinochloa crus-galli (L.) Beauv.) and other weeds in rice (Oryza sativa L.) (Schmidt et al., 1999; Webster et al., 1999; Williams, 1999). Recently, there has been interest in the use of bispyribac for annual bluegrass control in turfgrass. Annual bluegrass is a major weed in cool-season turfgrass that can tolerate low mowing and thrives in highly maintained turf areas such as athletic fields and golf course fairways and greens (Beard, 1973). Annual bluegrass can be difficult to selectively control postemergence in cool-season turfgrass with the herbicide options currently available to turf managers. Field studies have shown that bispyribac at 60 to $148 \mathrm{~g} \cdot \mathrm{ha}^{-1}$ can reduce populations of annual bluegrass in a creeping bentgrass stand without significantly injuring

Received for publication 16 Aug. 2004. Accepted for publication 2 Oct. 2004. We would like to thank Mike Bisbing and Nola Bobsin for their technical assistance, the farm crew at the Adelphia Research Center, and Valent USA Corp. for partial funding of this project.

${ }^{1}$ To whom reprint requests should be addressed; e-mail hart@aesop.rutgers.edu. turfgrass species under greenhouse conditions. Response of various cool-season turfgrass species to bispyribac applications under field conditions has not been well documented.

The objective of these studies was to determine the response of kentucky bluegrass, perennial ryegrass, tall fescue, and chewings fine fescue to applications of bispyribac under field conditions.

\section{Materials and Methods}

Field studies were conducted in 2002 and 2003 at the Rutgers Plant Science Research Center in Adelphia, New Jersey on 'Gnome' kentucky bluegrass, 'Jet' perennial ryegrass, 'Houndog 5' tall fescue, and 'Shadow II' chewings fine fescue. Soil type was a Holmdel sandy-loam (fine-loamy, mixed, active, mesic Aquic Hapludult) with a $\mathrm{pH}$ of 6.4 and organic matter content of $23 \mathrm{~g} \cdot \mathrm{kg}^{-1}$. Experiments were conducted on four separate fields each year (one species per field). Turfgrass stands were established in 2000. All fields were maintained at $4 \mathrm{~cm}$ mowing height and received similar water and nutrient applications within each year to ensure optimal growth. Studies were located on areas with $>95 \%$ ground coverage of the desired turfgrass. Herbicide treatments consisted of bispyribac(V-10029; 80\% a.i., wettable powder; Valent U.S.A. Corp., Walnut Creek, Calif.) at 0 (untreated control), 37, 74, 111, 148, and 296 $\mathrm{g} \cdot \mathrm{ha}^{-1}$. Treatments were applied to $0.9 \times 3 \mathrm{~m}$ plots with a single-nozzle $\mathrm{CO}_{2}$ backpack sprayer system using a 9504EVS nozzle tip (Spraying Systems Co., Wheaton, Ill.), which delivered $374 \mathrm{~L} \cdot \mathrm{ha}^{-1}$ of spray solution at $221 \mathrm{kPa}$. Treatments were applied to all turfgrass species on 11 June 2002 and to adjacent sites on 10 June 2003. Regular maintenance mowing continued as needed. At 35 and 70 d after treatment (DAT), clippings were collected and turf injury ratings were taken on a scale of $0 \%$ to $100 \%$, where 0 $=$ no injury and $100 \%=$ completely desiccated turf. Clippings were collected from the interior $0.5 \times 2.5-\mathrm{m}$ section of each plot using a standard walk-behind rotary mower with an attached collection bag and then oven-dried.

Experiments were conducted as randomized complete-block designs with four replications. Data were subjected to analysis of variance procedures and pooled across years when year by treatment interactions were not significant $(P=0.05)$. Regression analysis was used to fit clipping weight data to a four parameter logistic curve as described by Seefeldt et al. (1995) using SigmaPlot software (version 8.0; SPSS Inc., Chicago, Ill.). Visual injury data were fit to appropriate models using regression analysis. Transformation of data did not change analysis; therefore, actual means are presented. Direct statistical comparison between species was not appropriate because the studies were conducted on four separate fields each year. However, since bispyribac applications were synchronized and environmental conditions were similar for each species, relative differences in magnitude and duration of responses between the various species are discussed.

\section{Results}

Visual injury data for each species at each evaluation date were pooled across years. Clipping weight data for kentucky bluegrass at 35 DAT were separated by year due to a significant year by treatment interaction. Clipping weight data for perennial ryegrass, tall fescue, and chewings fine fescue at 35 DAT and clipping weight data for each of the four species at 70 DAT were pooled across years.

Kentucky bluegrass. Visual injury at 35 DAT increased with increasing bispyribac rate (Fig. 1). Injury reached $19 \%$ and $28 \%$ when bispyribac was applied at 148 and $296 \mathrm{~g} \cdot \mathrm{ha}^{-1}$, respectively. Injury was in the form of chlorosis, stunting, and thinning. Visual injury data at 70 DAT were fit to a linear model (Fig. 2). Injury dissipated to $<5 \%$ in plots treated with bispyribac at rates of 37 to $111 \mathrm{~g} \cdot \mathrm{ha}^{-1}$. However, injury was still evident 70DAT in plots treated with 148 and $296 \mathrm{~g} \cdot \mathrm{ha}^{-1}$. Applications of 74 to $296 \mathrm{~g} \cdot \mathrm{ha}^{-1}$ reduced clipping weights by $19 \%$ to $35 \%$, respectively, as compared to the un- 
treated control at 35 DAT in 2002 (Fig. 3). In 2003, clipping weights from bispyribac-treated plots were not significantly different from that of the untreated control despite visual injury symptoms. In 2003, plots received only $2.3 \mathrm{~cm}$ of rainfall in the three weeks preceding the 35 DAT evaluation, compared to $7.2 \mathrm{~cm}$ in 2002 (Fig. 4). Drier conditions in 2003 likely reduced kentucky bluegrass growth, indicated by lower clipping weights of the untreated control in 2003 as compared to 2002 (Fig. 3). Therefore, significant kentucky bluegrass growth may not have occurred during the weeks preceding the 35 DAT evaluation in 2003, yielding no detectable differences between clipping weights of treated and untreated plots. Pooled data revealed no significant treatment effects on kentucky bluegrass clipping dry weights at 70 DAT (data not shown).

Perennial ryegrass. Injury was less evident on perennial ryegrass than kentucky bluegrass. Initial turf injury (chlorosis) on ryegrass ranged from $4 \%$ to $16 \%$ at 35 DAT (Fig. 1 ) and by 70 DAT turf had almost completely recovered(Fig. 2). Clipping weight data revealed no significant perennial ryegrass stunting or thinning at 35 (Fig. 3) or 70 DAT (data not shown) from any bispyribac treatment.

Tall fescue. Response of tall fescue to bispyribac applications was similar to that of perennial ryegrass. Tall fescue injury was only $15 \%$ at 35 DAT when the highest rate of bispyribac (296 g·ha $\left.{ }^{-1}\right)$ was applied (Fig. 1).

Fig. 1. Visual turfgrass injury at $35 \mathrm{~d}$ after bispyribac treatment in 2002 and 2003.
Slight chlorosis (5\% to $10 \%)$ was evident at rates ranging from 37 to $148 \mathrm{~g} \cdot \mathrm{ha}^{-1}$. These initial chlorotic symptoms did not persist; by 70 DAT there was no significant tall fescue injury (Fig. 2). Like perennial ryegrass, tall fescue response to bispyribac was primarily in the form of chlorosis. No significant thinning or stunting was evident as measured by clipping weight data at 35 (Fig. 3 ) or 70 DAT (data not shown).

Chewings fine fescue. Fine fescue visual injury was comparable to that of perennial ryegrass and tall fescue. All bispyribac treatments discolored fine fescue turf, but injury was $<20 \%$ at 35 DAT (Fig. 1). Injury from all treatments dissipated to $5 \%$ or less by 70 DAT (Fig. 2). There were no significant reductions in fine fescue clipping weights at 35 DAT (Fig. 3). Fine fescue visual injury and clipping weight data were not collected at 70 DAT in 2002 due to overall poor turf quality caused by heat stress. In 2002, average daily temperatures exceeded $25^{\circ} \mathrm{C}$ on $28 \mathrm{~d}$ between 15 July and 20 Aug.; temperatures exceeded $30^{\circ} \mathrm{C}$ on 6 of those days (Fig. 4). During this same time period in 2003, average daily temperatures surpassed $25^{\circ} \mathrm{C}$ on $18 \mathrm{~d}$ but never exceeded $28^{\circ} \mathrm{C}$. Visual injury was $\leq 6 \%$ (Fig. 2) and there were no significant treatment effects on clipping weights (data not shown) at 70 DAT in 2003.

\section{Discussion}

Kentucky bluegrass is less tolerant to bispyribac than perennial ryegrass, tall fescue, and chewings fine fescue. Chlorosis of perennial ryegrass, tall fescue, and fine fescue was initially evident but turf had almost completely recovered from all treatments by $70 \mathrm{DAT}$. Initial injury on kentucky bluegrass was more severe and persistent than on the other species tested. In addition to chlorosis, bispyribac treatments also had potential to stunt and thin kentucky bluegrass stands especially at 148 and $296 \mathrm{~g} \cdot \mathrm{ha}^{-1}$. Research has demonstrated that these cool-season turfgrass species can also vary in their tolerance to otherherbicides. Sulfosulfuron, which inhibits acetolactate synthase like bispyribac, caused more severe and persistent injury on tall fescue than kentucky bluegrass, perennial ryegrass, or chewings fine fescue when applied at rates ranging from 6 to $67 \mathrm{~g} \cdot \mathrm{ha}^{-1}$ a.i. (Lycan et al., 2002). Other researchers demonstrated that fenoxaprop, which inhibits acetyl-CoA carboxylase (EC 6.3.4.15) in susceptible plants, at $0.20 \mathrm{~kg} \cdot \mathrm{ha}^{-1}$ a.i. and $0.40 \mathrm{~kg} \cdot \mathrm{ha}^{-1}$ caused no reduction in tall fescue, chewings fine fescue, or perennial ryegrass quality (Neal et al., 1990), while kentucky bluegrass was stunted and discolored following fenoxaprop applications at 0.14 and $0.28 \mathrm{~kg} \cdot \mathrm{ha}^{-1}$ (Bhowmik, 1986; Johnson, 1994).

Fagerness and Penner (1998) reported significant reductions in kentucky bluegrass, perennial ryegrass, tall fescue, and creeping red fescue clipping production at 5 weeks after a bispyribac application of $60 \mathrm{~g} \cdot \mathrm{ha}^{-1}$ in the greenhouse. However, all species continued to recover from suppression at 7 weeks after treatment. The greater level of injury that Fagerness and Penner observed as compared to our studies may be in part due to the use of a nonionic surfactant in their spray solutions, which has been shown to increase activity of
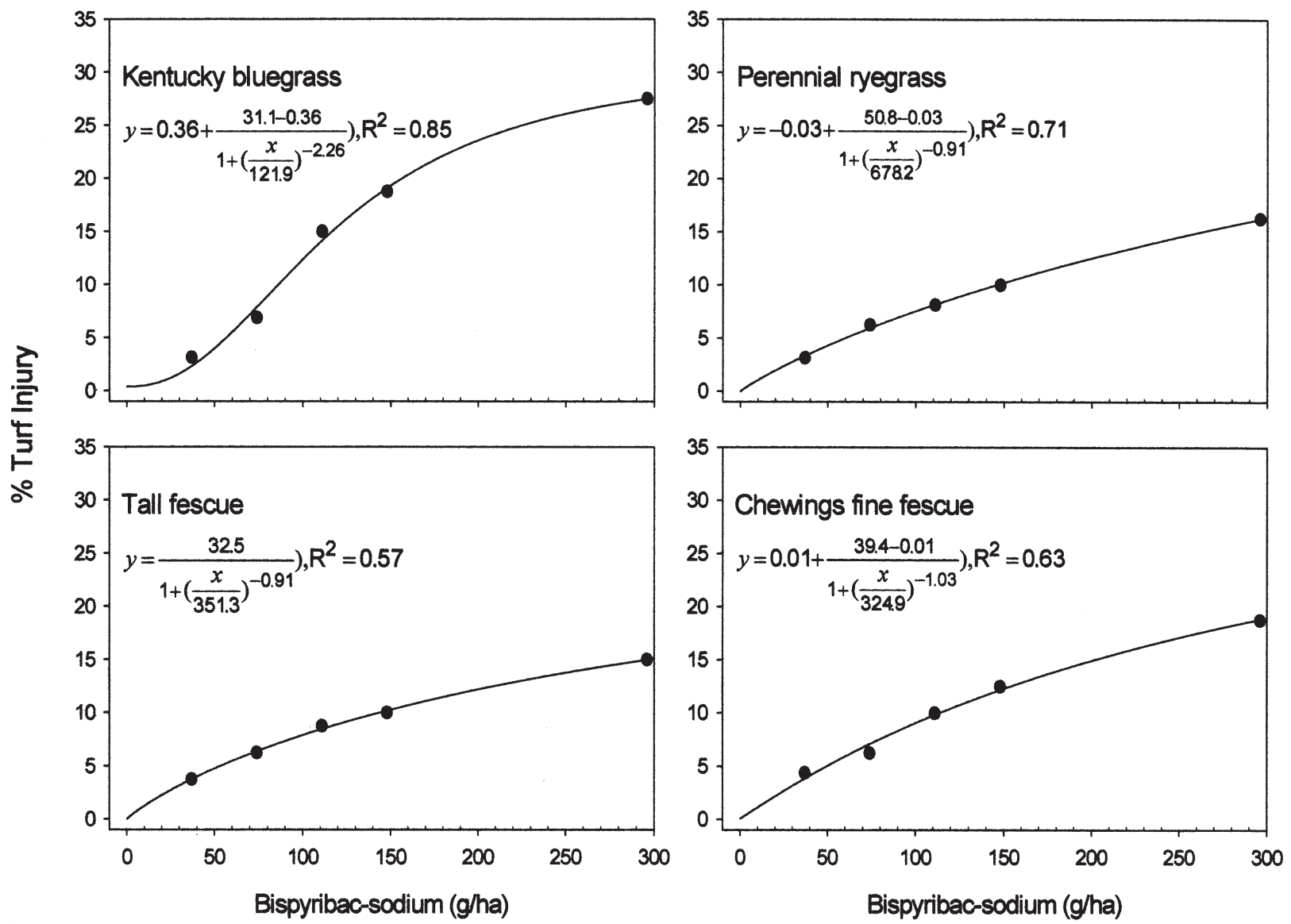

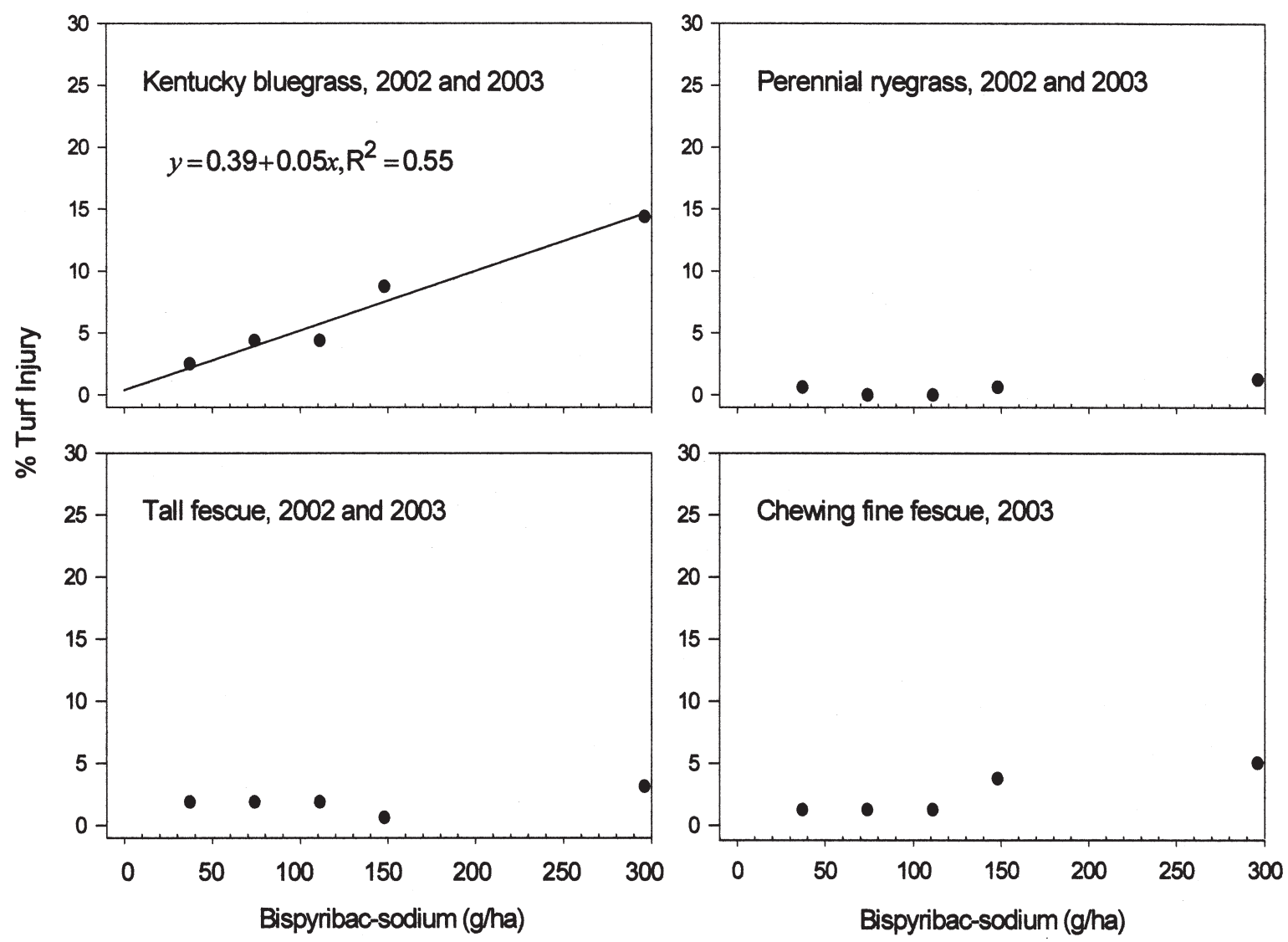

Fig. 2. Visual turfgrass injury at $70 \mathrm{~d}$ after bispyribac treatment. Injury data for perennial ryegrass and fescues were not regressed due to equivalent values at each bispyribac rate. Chewings fine fescue data for 2002 not included due to heat stress which reduced turf quality in all plots.
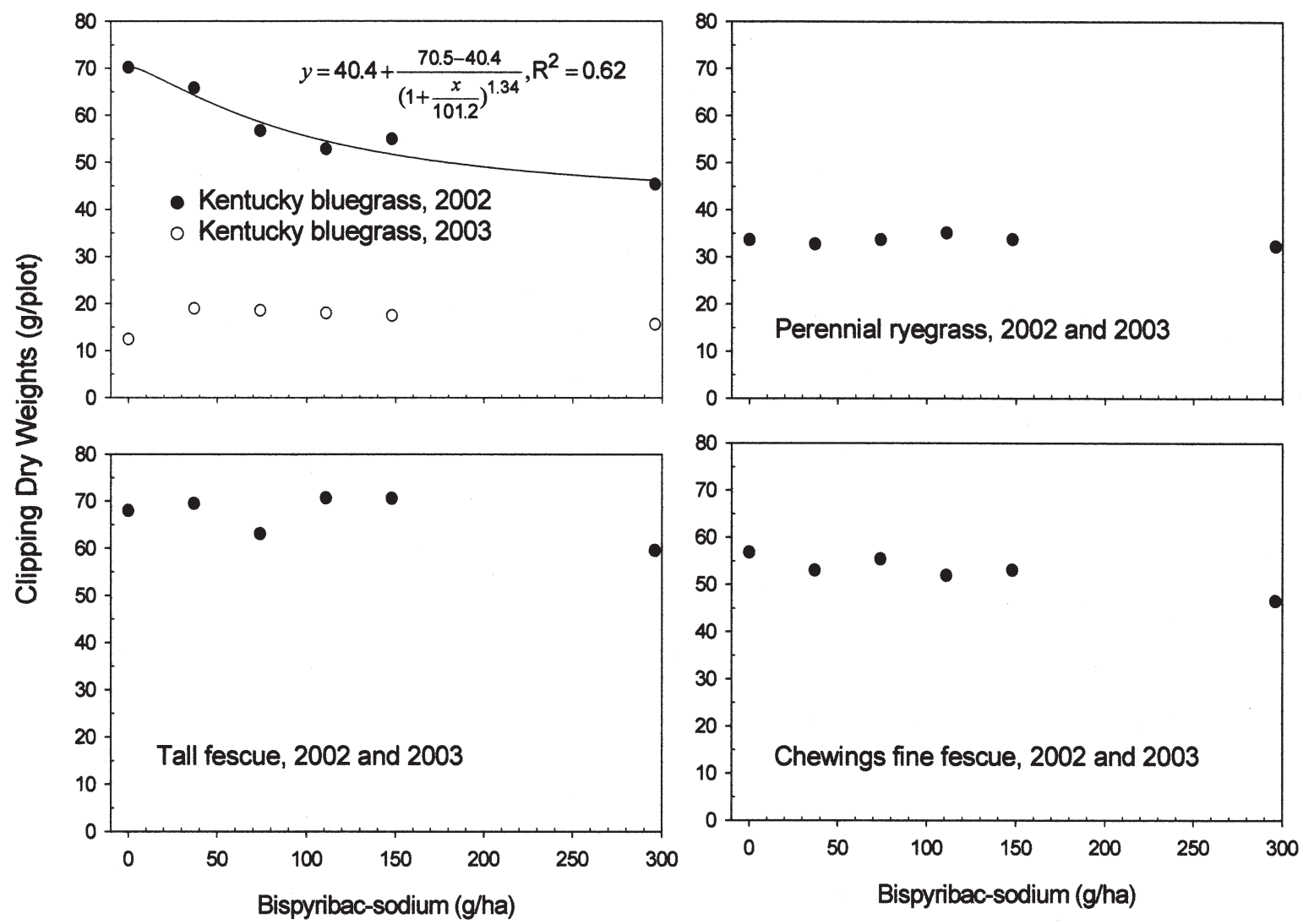

Fig. 3. Dry weights of clippings collected $35 \mathrm{~d}$ after bispyribac treatment. Kentucky bluegrass data is separated by year due to significant year by treatment interaction $(P<0.05)$. Clipping weight data for kentucky bluegrass in 2003 , perennial ryegrass, and fescues were not regressed due to equivalent weights at each bispyribac rate. 

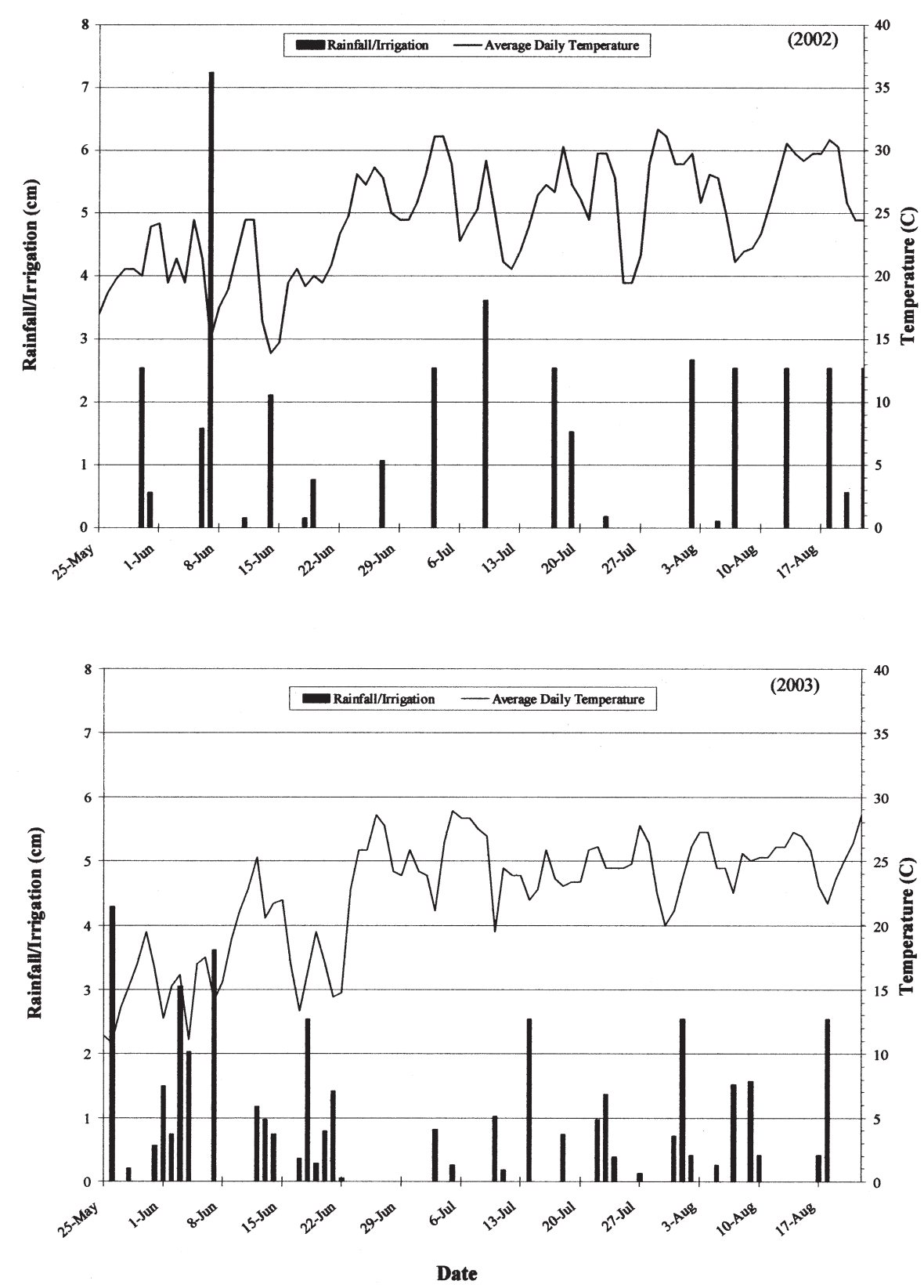

Fig. 4. Rainfall and irrigation distribution and average daily temperature at Adelphia Research Farm for 2002 and 2003. Applications were made on 11 June 2002 and 10 June 2003.

several herbicides (Wanamarta and Penner, 1989). In addition, it was noted that during the course of their experiments, annual bluegrass became evident in the turf plugs collected from the field. Therefore, some reductions in clipping production may have been due to reductions in annual bluegrass biomass

Our field studies suggest that turf managers can expect some minor damage when bispyribac populations. Therefore, further research could investigate the recuperative abilities of these turfgrass species when multiple applications of bispyribac are applied. Turf managers may consider bispyribac injury on kentucky bluegrass to be unacceptable at rates of $\geq 74 \mathrm{~g} \cdot \mathrm{ha}^{-1}$. However, the wide range of genetic diversity within kentucky bluegrass warrants further research to determine if cultivars exist that are more tolerant to bispyribac.

\section{Literature cited}

Beard, J.B. 1973. Cool season turfgrasses, p. 54-131. In: Turfgrass: Science and culture. Prentice-Hall, Englewood Cliffs, N.J.

Bhowmik, P.C. 1986. Fenoxaprop-ethyl for postemergence crabgrass control in kentucky bluegrass turf. HortScience 21:457-458.

Fagerness, M.J. and D. Penner. 1998. Evaluation of V-10029 and trinexapac-ethyl for annual bluegrass seedhead suppression and growth regulation of five cool-season turfgrass species. Weed Technol. 12:436-440.

Johnson, B.J. 1994. Herbicide programs for large crabgrass and goosegrass control in kentucky bluegrass turf. HortScience 29(8):876-879.

Lycan, D. W., S. E. Hart, and D. C. Riego. 2002. MON 44940: A potential new herbicide for

weed management in turfgrass species. Proc. Northeastern Weed Sci. Soc. 56:111.

Lycan, D. W., S. E. Hart, and J. Fausey. 2003. Potential use of V-10029 for weed control in cool-season turfgrass. Proc. N.E. Weed Sci. Soc. 57:96.

Neal, J.C., P.C. Bhowmik, and A.F. Senesac. 1990. Factors influencing fenoxaprop efficacy in coolseason turfgrass. Weed Technol. 4:272-278.

Park, N., Y. Suto, Y. Miura, N. Nakatani, S. Iori, and M. Ogasawara. 2002. Annual bluegrass (Poa апnи $\mathrm{L}$.) control in bentgrass (Agrostis palustris Huds.) green with sequential application of bispyribac-sodium combined with dinitroanalines. Weed Biol. Mgt. 2:159-162.

Schmidt, R.E., F.L. Talbert, J.S. Baldwin, E.F. Rutledge, E.F. Scherder, and C.C. Wheeler. 1999. Performance of V-10029 (bispyribac-sodium) in rice weed control programs. Proc. S. Weed Sci. Soc. 52:49-50.

Seefeldt, S.S., J.E. Jensen, and E.P. Fuerst. 1995. Log-logistic analysis of herbicide dose- response relationships. Weed Technol. 9:218-227.

Shimizu, T., I. Nakayama, K. Nagayama, T. Miyazawa, and Y. Nezu. 2002. Acetolactate synthase inhibitors, p. 1-41. In: P. Böger, K. Wakabayashi, and K. Hirai (eds.). Herbicide classes in development: Mode of action, targets, genetic engineering, chemistry. Springer-Verlag, New York.

Wanamarta, G. and D. Penner. 1989. Foliar penetration of herbicides. Rev. Weed Sci. 4: 215-231.

Webster, E.P., W. Zhang, D.Y. Lanclos, J.A. Masson, and S. N. Morris. 1999. Experimental herbicides for weed control in rice. Proc. S.Weed Sci. Soc. $52: 16-17$.

Williams, B.J. 1999. Barnyardgrass (Echinochloa crus-galli) control in dry-seeded rice with V10029. Proc. S. Weed Sci. Soc. 52:50. 